\title{
Study of the gas content in aluminum alloys
}

Dana Bolibruchová, Lukáš Richtárech

Department of Technological Engineering, Faculty of Mechanical Engineering, University of Žilina, Univerzitná 1, 010 26, Slovak Republic, Email: danka.bolibruchova@fstroj.uniza.sk

This article deals with the gas content of aluminum alloys and prediction of gas content using the foundry simulation software. In the theoretical section summarizes the main causes of gas content of aluminum alloys, the effects of modifications and inoculation, as the survey gas content and the possibility of using simulation software for predicting the gas content. The experimental part is tested for gas content $f$ the test castings and verificated by simulation program ProCAST. As an experimental alloy was used AISi7Mg0,3. The specimens were evaluated using four methods: microscopically, macroscopically, using a stereomicroscope and by evaluating the density. This type of experiment was performed at the Department of Technological Engineering for the first time, simulation of the gas content and its verification by this method can be considered as a unique.

Keywords: gas content, porosity, simulation, aluminum alloys

\section{Acknowledgements}

This project is solved under the financial support of VEGA number 1/0363/13 Authors would like to thank for their support.

\section{References}

[1] ROUČKA, J. (2004). Metallurgy of Non-ferrous alloys. Brno. 1. Edition. VUT Brno, 2004, 148 p. ISBN 80214-2790-6.

[2] PEQUET, CH. - GREMAUD, M. - RAPPAZ, M. (2002). Modeling of Microporosity, Macroporosity, and PipeShrinkage Formation during the Solidification of Alloys Using a Mushy-Zone Refinement Method: Applications to Aluminum Alloys. In Metallurgical and Materials Transactions. 2002, vol. 33A. p. 2095-2106.

[3] ROUČKA, J. et al. (2007). Influence of gas content and cooling rate on the structure, porosity and mechanical properties of castings made from AlSi9Cu3 alloy. In Technological Engineering. ISSN 1336-567. 2007 , vol. 4. p. $25-28$.

[4] CAMPBELl, J. (2003). Castings. 2. Edition. Oxford : Butterwort - Heinemann, 2003, 329 p. ISBN 0-75064790-6.

[5] SAMUEL, A.M, SAMUEL, F.H. (1992). Porosity Factor in Quality Aluminum Castings. In AFS Transactions. 1992, vol. 100, p.657-666

[6] http://www.esi-group.com/

[7] BRŮNA, M., SLÁDEK, A., KUCHARČÍK, L. (2012). Formation of porosity in Al-Si alloys. In Archives of foundry engineering. ISSN 1897 - 3310, 2012, volume 12, Issue 1/2012, p. 5-8.

[8] PASTIRČÁK, R., URGELA, D., BRŮNA, M. (2011). Infuence of various opening materials on the mechanical properties and dilatation of moulding mixtures. In International foundry research: official journal of the World Foundry Organization. ISSN 0046-5933. Vol. 63, no. 4 (2011), pp. 2-6.

[9] MICHALCOVÁ, A., VOJTĚCH, D. (2012). Structure of rapidly solidified aluminium alloys. In Manufacturing Technology. ISSN 1213-2489. vol. 12, p.166-169.

[10] LIPIŃSKI, T. (2011). Use Properties of the AlSi9Mg Alloy With Exothermical Modifier. In Manufacturing Technology. ISSN 1213-2489. vol. 11, p. 44-49.

[11] JAVOŘÍK, J. 2003. Využití metody konecných prvku pro materiýlovou analýzu nekovových materiálu. In Strojírenská technologie. ISSN 1211-4162. vol. 8, p. 12-16.

[12] HAUPTVOGEL, J., JANDEČKA, K. (2006). Využiti metod FEM při modelovani procesů v technologii. In Strojírenská technologie. ISSN 1211-4162. vol. 11. p. 17-19. 